УдК 315:351.86

М.І.Балан,

здобувач кафедри глобалістики, євроінтеграчії та управління начіональною безпекою, Начіональна академія державного управління при Президентові Украӥни

DOI: $10.32702 / 2306-6814.2019 .5 .152$

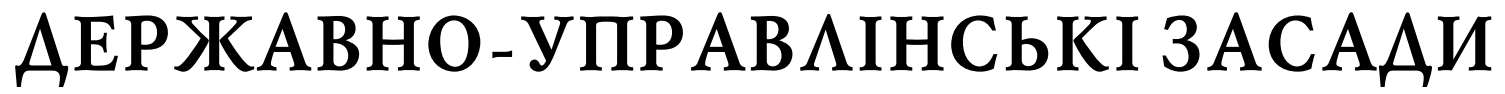 ЗАБЕЗПЕЧЕННЯ СУСПІ $Ь Н О$ - ПОАІТИЧНОЇ СТАБІ $\Lambda$ СНОСТ
}

\author{
M. Balan, \\ applicant of the Department of Globalistics, European Integration and National Security, \\ National Academy of Public Administration, the President of Ukraine
}

\section{STATE-MANAGEMENT PRINCIPLES OF PROVISION SOCIAL AND POLITICAL STABILITY}

\begin{abstract}
Суспільно-політичну стабільність як стан соціумуза умов домінування його статичних ознак над динамічними необхідно розглядати на основі теорії національної безпеки. Виклики, загрози й небезпеки, що постають як ризики, спрямовані не лише проти стабільних характеристик суспільства, а й національної безпеки в цілому. Умовою повернення суспільства до стабільних характеристик життєдіяльності (відновлення суспільно-політичної стабільності) є використання відповідних державно-управлінських механізмів, загальна спрямованість яких пов 'язана із забезпеченням національної безпеки. Це завдання потребує використання відповідного понятійно-категоріального апарату, диференційованого на кілька рівнів. Перший рівень - це базові поняття "стабільність" $і$ "нестабільність". В окремих випадках застосовується термін "стійкість", який має стратегічне значення. До другого рівня категоріального апарату теорії державного управління відносяться поняття "дестабілізація", "технологія дестабілізації політичної та економічної систем", "загрози суспільно-політичній стабільності", "стабілізація". До третього (організаційно-практичного) рівня належать поняття та вирази на кшталт "технології державного реагування на загрози національній безпеці", "методи державного реагування на загрози національній безпеці", "профілактика та протидія загрозам суспільно-політичній стабільності", "система профілактики та протидії загрозам суспільно-політичній стабільності", "механізм профілактики загрозам суспільно-політичній стабільності", "комплексний механізм протидії загрозам суспільно-політичній стабільності". Як наслідок, понятійно-категоріальний апарат проблематики забезпечення суспільно-політичної стабільності дає змогу в ідеалізованому вигляді уявити собі ті чи інші сторони цього процесу, виокремити суттєві елементи та їх взаємозв'язок, побудувати план практичних дій, спрямованих на стабілізацію суспільства в контексті забезпечення національної безпеки.
\end{abstract}

Socio-political stability as a state of society in the conditions of dominance of its static characteristics over dynamic should be considered on the basis of the theory of national security. The challenges, threats and dangers posed as risks are directed not only against the stable characteristics of society, but also national security in general. Their integral result is both social destabilization and a decrease in the security indicators of society. We have a case where the theory of the middle level (the theory of social stability) is considered on the basis of the theory of a higher level (the theory of national security).

The condition of returning a society to stable characteristics of life (restoration of social and political stability) is the use of appropriate state-management mechanisms, the nature of which is connected 
with the provision of national security. This task requires the use of an appropriate conceptualcategorical apparatus, differentiated into several levels. The first level is the basic concepts of "stability" and "instability" that have a tactical load. In some cases, the term "stability" is of strategic importance. To the second level of the categorical apparatus of the theory of state administration are the notion of "destabilization", "technology of destabilization of political and economic systems", "threats to social and political stability", "stabilization".

The third level (organizational and practical) includes concepts and expressions such as "state response to threats to national security", "methods of state response to threats to national security", "prevention and counteraction to threats to social and political stability", "prevention and counteraction system" threats to social and political stability", "mechanism for preventing threats to social and political stability", "comprehensive mechanism for countering threats to social and political stability". As a result, the conceptual-categorical apparatus of the problems of ensuring socio-political stability enables to imagine some aspects of this process in an idealized way, to distinguish the essential elements and their interrelations, to develop a plan of practicalactions aimed at stabilizing the society in the context of providing national security.

The interconnection and hierarchy of concepts: "social and political stability - a system of prevention and counteraction to threats to social and political stability-mechanisms for prevention and counteraction to threats to social and political stability" and their essence allow to state the following. The subordination of terms must necessarily be taken into account when preparing the following documents: The Doctrine of Socio-Political Stability - Strategy of Socio-Political Stability - The State Target Program for Ensuring Social and Political Stability.

In the case of adherence to the proposed sequence of normative legal acts, the development of doctrinal foundations of social stability, the formation and functioning of strategic principles for countering threats to socio-political stability, and the organization of public administration of this system will adopt a clearer, logically grounded and completed process.

Ключові слоВа: суспільно-політична стабільність, суспільно-політична дестабілізація, начіональна безпека, держаВне упраВління, понятійно-категоріальний апарат, норматиВно-праВові документи.

Key words: socio-political stability, socio-political destabilization, national security, state administration, conceptual-categorical apparatus, legal documents.

\section{ПОСТАНОВКА ПРОБАЕМ У ЗАГААЬНОМУ ВИГАЯАI}

Забезпечення суспільно-політичної стабільності в автономному розумінні цього процесу, відірваного від тенденцій та закономірностей загальносуспільного розвитку, можливе лише у частковому вигляді. Реальною виглядає локальна (місцева) стабілізація фрагменту соціуму, яка не може бути довготривалою у випадку постійного впливу на нього різнопланових загроз і ризиків. Всеосяжна (системна) стабілізація є можливою лише за умови задовільного розв'язання питання більш високого порядку - забезпечення національної безпеки. Остання, виступаючи станом захисту життєво важливих інтересів людини, суспільства і держави, іманентно вбирає в себе забезпечення суспільної стабільності. Забезпечення національної безпеки у свою чергу $є$ залежним від рівня теоретичного усвідомлення сукупності взаємопов'язаних проблем, що виникають у тандемі "безпека - стабільність", зокрема, глибини й досконалості відповідного понятійно-категоріального апарату. Становлення необхідної сукупності термінів, виразів, визначень в сучасній Україні триває. Проте вже зараз можна стверджувати про можливість системного планування діяльності у сорері забезпечення суспільно-політичної стабільності на вербальній основі теорії національної безпеки.

\section{AHА $\Lambda$ О ОСТАНHIX АОС $А$ АЖЕНЬ І ПУБАІКАЦІЙ}

Теоретичні підвалини державного управління, включно з регулюванням соціально-політичних процесів викладено у працях Р. Войтович, В. Голубь, Л. Гонюкової, Н. Грицяк, О. Лазор, І. Пантелейчук, О. Петроє, О. Пухкала, Н. Рингач, А. Савкова, Г. Ситника, І. Сурай, О. Суходолі, С. Телешуна, інших дослідників. Розробка понятійно-категоріального апарату проблематики національної безпеки, визначення семантичних і лінгвістичних зв'язків між ключовими термінами з метою поглиблення їх змісту здійснено у працяхВ. Абрамова, О. Бортнікової, Л. Весельської, А. Дацюка, Т. Запорожець, Д. Кучми, В. Кириленка, В. Мандрагелі, Р. Марутян, Ю. Мельника, О. Пошедіна, Г. Ситника, В. Смолянюка, 
М. Шевченка, Л. Шипілової та ін. Різні аспекти конфрліктної взаємодії соціальних суб'єктів із позицій науки державного управління розглянули Н. Довгань, Т. Запорожець, Т. Сенюшкіна, В. Тимофрієв, Н. Федчун. Разом з тим і тематика забезпечення національної безпеки як складника державного управління, і питання стабілізації суспільних відносин в межах націєбезпечної проблематики залишаються далекими від завершення, що стимулює їх подальше наукове висвітлення.

\section{ЦІ $\Lambda$ I СТАТТІ}

Довести подальше удосконалення понятійно-категоріального апарату теорії національної безпеки та теорії забезпечення суспільно-політичної стабільності як її складової. 3 цією метою використати законодавство України з питань національної безпеки. У категоріальному просторі теорії державного управління виокремити рівні вербального позначення різних аспектів діяльності з питань забезпечення суспільно-політичної стабільності. На цій основі вказати на можливість оптимізації процесу розробки підзаконних нормативно-правових документів, що стосуються суспільно-політичної стабільності.

\section{ВИК ААА ОСНОВНОГО МАТЕРІААУ АОС $\triangle А$ ЖЕННЯ}

Методологічні питання дослідження державноуправлінських проблем забезпечення національної безпеки в сучасних умовах $є$ надзвичайно актуальними та вимагають подальшого вивчення й поглиблення. Це передбачає розвиток відповідного понятійно-категоріального апарату, встановлення субординаційних та структурно-фрункціональних зв'язків між поняттями і категоріями та розробку на цій основі відповідних моделей державного управління національною безпекою. Це важливо з огляду на те, що проблематика забезпечення суспільно-політичної стабільності була й залишається складовою більш загальної націєбезпечної проблематики.

Незважаючи на значний науковий доробок вітчизняних дослідників з питань формування понятійно-категоріального апарату національної безпеки, теорії державного управління в цілому, маємо констатувати, що ця робота залишається незавершеною (особливо в контексті європейської та євроатлантичної інтеграції України). Зацікавлений загал потребує нових підходів, здатних удосконалити розуміння національної безпеки відповідно до західних демократичних стандартів, наситити термінологічний апарат вербальними конструктами, які одночасно адекватно відбивають дійсність, $\epsilon$ несуперечливими у взаємних перекладах та залишаються реально віддаленими від ідеологічних підтекстів, присутніх у "стабільних" суспільствах авторитарного гатунку. Безпосередньо це стосується питань забезпечення суспільно-політичної стабільності, оскільки демократична стабільність корінним чином відрізняється від свого авторитарного (тоталітарного) антиподу. Це стосується широкого кола термінів, понять, категорій, словосполучень, на основі яких державні органи та громада усвідомлюють складну дихотомію "стабільність - нестабільність" і в історичному контексті, і в конкретних ситуаціях.
Засади державної політики національної безпеки, спрямованої на захист національних інтересів і гарантування в Україні безпеки особи, суспільства і держави від зовнішніх і внутрішніх загроз в усіх сорерах життєдіяльності, свого часу (у 2003 р.) були визначені в Законі України "Про основи національної безпеки України" [1], який став першим цільовим законодавчим актом, побудованим на частковому врахуванні західного досвіду. Ключовим у цьому Законі стало визначення поняття "національна безпека". Критично зауважимо, що визначення було занадто розлогим, спрямованим на охоплення максимально можливої кількості суспільних сфер щодо яких доречним було застосувати націєбезпечну методологію (методику). Проте суспільне значення цього терміну та побудованого на його основі інших понятійно-категоріальних конструкцій є беззаперечним: від адекватного усвідомлення висхідних категорій залежить успіх нації у життєво важливих, фактично доленосних справах. Отже, законодавча новизна стосувалась широкого кола термінів на кшталт "національних інтересів", "загроз національній безпеці", "суб'єктів" та "об'єктів" національної безпеки, "системи національної безпеки", "системи забезпечення національної безпеки", "напрямів державної політики національної безпеки" тощо. Доречно нагадати, що до пріоритетів національних інтересів України Закон відносив "зміцнення політичної і соціальної стабільності в суспільстві", яка таким чином набувала статусу базисного елементу в загальній діяльності суспільства і держава у сфері національної безпеки.

На основі розробленості пакету "стартових" понять можливою стає розробка відповідних державно-управлінських підходів з націєбезпечних питань. Проте це завдання було (й залишається) доволі складним. Як слушно зауважив В. Абрамов, "умовою успішного розв'язання комплексної проблеми забезпечення національної безпеки $є$ фрормування адекватної наявним та очікуваним загрозам системи управління у сорері національної безпеки. При цьому принципово важливим $є$ те, що створення необхідних умов (насамперед забезпечення належного соціально-економічного розвитку), фрормування та ефективне функціонування вказаної системи мають відбуватися одночасно" [2, с. 13].

Наступним важливим кроком на шляху оптимізації державно-управлінських впливів на сфері національної безпеки стало прийняття чинного на тепер Закону України від 20.06.2018 р. "Про національну безпеку України" [3]. Закон радикально відрізняється від свого попередника. Вкажемо лише на деякі відмінності. Насамперед, відбувся перехід від "пріоритетів національних інтересів" (яких у Законі 2003 р. було 11) до "фундаментальних національних інтересів", яких у 2018 р. зафіксовано набагато менше. Ними, зокрема, названі:

1) державний суверенітет і територіальна цілісність, демократичний конституційний лад, недопущення втручання у внутрішні справи України;

2) сталий розвиток національної економіки, громадянського суспільства і держави для забезпечення зростання рівня та якості життя населення;

3) інтеграція України в європейський політичний, економічний, безпековий, правовий простір, набуття членства в Європейському Союзі та в Організації Пів- 
нічноатлантичного договору, розвиток рівноправних взаємовигідних відносин з іншими державами.

Звернімо увагу на високий рівень абстрагування життєво важливих інтересів людини, суспільства і держави, яких у реальних відносинах існує занадто багато. Практично всі вони є (можуть бути) похідними від фундаментальних інтересів. "Суверенітет", "територіальна цілісність", "демократія", "Конституція", "економіка", "недопущення втручання", "громадянське суспільство", "держава", "рівень життя населення", "ЄС", "НАТО" та ін. терміни слід вважати ключовими визначеннями, що об'єднують та систематизують індивідуальні, групові (суспільні) та державні інтереси, а також окреслюють контур внутрішніх і зовнішніх перетворень в Україні на тривалу перспективу.

Крім того, у Законі цілком очікувано відбулося суттєве розширення термінологічного ряду, що безпосередньо стосується питань національної безпеки та способів її забезпечення. Йдеться про "воєнний конфрлікт", "воєнну безпеку", "громадську безпеку і порядок", "державну безпеку", "демократичний цивільний контроль", "збройний конфлікт", "оборонний огляд", "оборонне планування", "оборонно-промисловий комплекс", "планування у сорері національної безпеки", "сектор безпеки і оборони", "сили безпеки", "сили оборони", інші поняття. В сукупності вони створюють потенціал істотного підвищення якості націєбезпечного аналізу, прогнозу, а головне - націєбезпечної діяльності. Деякі з цих термінів (насамперед громадська безпека і порядок, воєнна безпека, державна безпека) безпосередньо стосуються суспільно-політичної стабільності, дозволяючи аналізувати її як з державно-управлінських, так і громадських позицій.

Стан справ дещо погіршується у зв'язку з відсутністю іншого важливого документу, розробка якого передбачена Законом України від 20.06.2018 р. "Про національну безпеку України". Йдеться про Стратегію громадської безпеки та цивільного захисту населення. Поки що цей документ не прийнято. Проте неважко здогадатись, що на його сторінках подальший розвиток отримають базисні терміни, що стосуються суспільно-політичної стабільності. Потребу в цьому відчувають усі зацікавлені сторони, причетні до посилення стабільних ознак життєдіяльності українського суспільства з одночасним зниженням їх нестабільних антиподів.

Разом з тим, наявний понятійно-категоріальний апарат дозволяє поєднати "чисте" теоретизування з питань безпеки і стабільності з практичними схемами її забезпечення. Зокрема в рамках системно-діяльнісного підходу щодо забезпечення безпеки, запропонованого Д. Кучмою [2, с. 58-85], окреслимо загальні межі понятійно-категоріального апарату проблематики забезпечення суспільно-політичної стабільності. Попередньо зауважимо, що термінологічне поле науки державне управління (у тому числі в частині забезпечення суспільно-політичної стабільності) вимагає групування категорій за певними критеріями. У категоріальному ресурсі теорії державного управління пропонується виокремити кілька рівнів. До першого рівня належать поняття та категорії, що стосуються концептуального ядра загальної проблеми забезпечення стабільності. До другого рівня - поняття та категорії, що відображають проце- си дестабілізації та стабілізації суспільно-політичної ситуації. До третього рівня належать практичні поняття та категорії, що відображають організацію суб'єктом процесу державного управління системи профілактики та протидії загрозам суспільно-політичній стабільності.

До першого із вказаних рівнів належать базові поняття "стабільність" та "нестабільність". Поняття стабільності у політичних відносинах системно досліджено О. Литвиненком [4, с. 74]. Він виділяє наступні підходи щодо визначення стабільності. Згідно з ними, стабільність розглядається як наслідок чогось, як несамостійне, похідне поняття. Наприклад: 1. Стабільність як стан відсутності загрози нелегітимного насильства (Ф. Білі, К. Даудинг, Р. Кімблер, Д. Яворські). 2. Стабільність як відсутність змін уряду (Е. Циммерман). 3. Стабільність як відсутність змін у конституційному ладі, правилах гри (С. Хантінгтон). 4. Стабільність як відсутність структурних змін (Д. Сіаринг). 5. Стабільність як стан балансу політичних сил (Дж. Лівелі). 6. Стабільність як легітимність влади та підтримка її фундаментальних цінностей (С. Ліпсет, Дж. Заллер). 7. Стабільність як фективна економіка та інституційний розвиток (Е. Даффф, Д. Маккамант). 8. Стабільність як адаптаційні можливості суспільно-політичної системи та її здатність управляти структурними змінами (Т. Парсонс). Аналізуючи суспільні процеси методом "від супротивного", О. Литвиненко зазначає, що політична стабільність визначається через певне заперечення, відсутність (у даному випадку - через відсутність суспільних збурень).

Як вважає Г. Ситник, політична стабільність - це такий стан системи зв'язків між різними політичними суб'єктами, який характеризується певною цілісністю політичної системи, її здатністю ефективно реалізовувати покладені на неї функції. Розрізняють внутрішньополітичну, регіональну та міжнародну політичну стабільність. Головними суб'єктами, які забезпечують внутрішньополітичну стабільність, $€$ суспільно-політичні інститути держави та інститути громадянського суспільства [5, с. 389-390].

На переконання О. Руденко, суспільна стабільність це стан суспільства, для якого характерна певна стійкість, єдність, цілісність, здатність до ефективних та конструктивних дій, який виявляється у відсутності криз та насильства. Суспільна стабільність дає змогу ставити й вирішувати масштабні завдання розвитку, запобігає непродуктивним витратам ресурсів на подолання кризових явищ у суспільстві [5, с. 671].

За визначенням В.Гошовської, політична стабільність - це міцність, стійкість положення влади в їі основних ланках і регіонах; неослабна підтримка стану стійкості [6, с. 628].

На думку М. Шевченка, суспільно-політична стабільність - це стан суспільства та політичної системи, для якого характерна певна стійкість, єдність, цілісність, здатність до ефрективної та конструктивної взаємодії по досягненню цілей суспільного розвитку, а також мобілізації всього потенціалу держави й суспільства для захисту власних інтересів, подолання небезпеки [7, с. 51].

Виходячи з наведених визначень, можна дійти висновку, що передумовами суспільно-політичної стабільності є: 
стабільна економіка. Економічні питання навіть у постмарксистський період сприймаються як надзвичайно важливі у загальній палітрі суспільної життєдіяльності;

рівновага між владними структурами. Жодна політична група, жоден соціальний інститут не повинні панувати над всіма іншими;

наявність у суспільстві хоча б елементарної злагоди. У її формуванні важливу роль відіграють засоби масової інфрормації, які здатні відчужувати або об'єднувати громадян навколо політичного керівництва;

наявність ефективного державного управління. Значення держави в сучасних умовах важко переоцінити. Державотворчі проекти були й залишаються альфою і омегою політичної активності. Криза анархістської ідеології в сучасних умовах багато в чому пояснюється ставкою зацікавлених сил на державу як головний інструмент відстоювання національних інтересів.

Варто уточнити, що стабільність співвідносять з оперативними й тактичними параметрами політичної динаміки, а стійкість - зі стратегічними. Відштовхуючись від цього, Р.Арон визначив наступні умови суспільної стійкості: узгодженість конституційних правил із системою партій; гармонія конституційних правил і партійних прагнень, з одного боку, і соціальної структури та вподобань суспільства - з іншого [8, с. 123]. Проаналізувавши британську та американську політичні системи, цей дослідник доводить, що стійкість та ефективність забезпечуються не стільки конституційними правилами як такими, а гармонією цих правил та партійної системи, природою партій, їхніми програмами, політичними концепціями. Тобто у випадку, коли б партії мали діаметрально протилежні погляди на курс політичного чи економічного розвитку - це дестабілізувало б ситуацію в країні.

Стабільність доволі часто проявляється як результат тактичних угод між основними політичними силами, як баланс, рівновага. Проте вона не може бути довготривалою. Після періоду стабільності можуть бути як модернізаційний ривок до нової стратегічної стійкості, так і стагнація й дестабілізація, що ведуть до нестійкості політичної системи. О. Литвиненко наводить такі визначення нестабільності: 1. Нестабільність $€$ станом наявності "чогось" за умов слабкості, або неефективності компенсуючих механізмів. 2. Нестабільність - це зміна правил політичної гри, до якої політична система неспроможна адаптуватися. 3. Нестабільність - це стан невизначеності траєкторії розвитку, можливість вибору напряму з кількох можливих. Інакше кажучи, нестабільність - суттєва характеристика зони біфуркації [4, с. 74-75].

На думку О. Литвиненка, досить важливим $€$ той факт, що "за умов затягування часових показників стану нестабільності у соціально-політичних системах спрацьовує цікава закономірність. Система адаптується до постійної зміни правил гри, починає жити фактично без правил, точніше, за правилами зміни правил. Назвемо цей стан квазістабільним. Феномен квазістабільності полягає у тім, що за умов швидкої зміни правил гри в кожен конкретний момент ці правила $є$ стабільними, тобто має місце ефект локальної стабільності. Понад те, квазістабільність має місце виключно за стабільності правил гри на одному з можливих рівнів. Ці правила можуть бути не загальнозначущими, неофіційними, невизнаними більшістю, але з ними погоджуються та їх дотримуються основні гравці. Таким чином, підгрунтям квазістабільності є певна соціальна згода (консенсус), а через це - певна стабільна база. Можна уявити собі систему, що взагалі не має жодних загальновизнаних правил функціонування, але має загальновизнаний напрям розвитку та постійну швидкість змін (стабільну першу похідну за часом). Перехідне суспільство за визначенням, запропонованим вище, є принципово нестабільним чи, у кращому разі, квазістабільним" [4, с. 75].

Виходячи з наведених визначень нестабільності, можна дійти висновку, що передумовами суспільно-політичної нестабільності $€$ :

нестабільна, неефективна, несучасна, залежна від зовнішніх впливів економіка;

розкол політичної еліти у питаннях щодо встановлення прийнятних правил гри, наслідки чого прямо чи опосередковано ретранслюються на все суспільство;

порушення рівноваги між функціонуючими владними структурами як за рахунок внутрішніх причин, так і зовнішніх впливів;

відсутність у суспільстві злагоди з ключових питань, насамперед розуміння національних інтересів, національних цінностей, стратегічних векторів спільного руху; поширення корупції та інших негативних явищ в органах державної влади та інші причини.

Додамо до цього ще одну передумову, дію якої в сучасних умовах відчуває все українське суспільство. Якщо до 2014 р. загальноукраїнська стабільність могла бути визначена як "рівнодіюча локальних нестабільностей" внутрішнього походження, то після відомих подій (анексії Криму російськими військами, їх вторгнення у східні райони Донеччини і Луганщини, широкого застосування технологій гібридної війни проти українського суспільства і держави тощо) джерелом дестабілізаційних впливів слід вважати РФ, метою яких є послаблення й знищення української державності. Ця передумова за своїм значенням не поступається названим вище, а за результатами практичного прояву навіть перевищує їх.

До другого рівня категоріального апарату теорії державного управління, що стосується забезпечення суспільно-політичної стабільності, відносяться поняття "дестабілізація", "технологія дестабілізації політичної та економічної систем", "загрози суспільно-політичній стабільності", "стабілізація".

Під дестабілізацією Ю.Сурмін пропонує розуміти процес втрати стабільності, рівноваги системи, погіршення її функціонування [5, с. 165]. Під технологією дестабілізації політичної та економічної систем пропонуємо розуміти спосіб реалізації претендентами на владу (групами населення, котрі мають ресурси для впливу на уряд) конкретного складного процесу політичної (економічної) дестабілізації шляхом розчленування його на систему послідовних взаємопов'язаних процедур та операцій, які виконуються більш-менш однозначно і мають на меті досягнення високої ефективності ініціювання політичної нестабільності.

Під загрозою суспільно-політичній стабільності пропонуємо розуміти безпосередню можливість виникнен- 
ня суспільно-політичної кризи в країні, яка буде супроводжуватися делегітимізацією правлячої еліти, тиском на владу, її неконституційною зміною, що врешті-решт призведе до руйнування основ державності. За сорерами прояву можна виділити загрози суспільно-політичній стабільності в духовній, інформаційній, соціальній, внутрішньополітичній, економічній, екологічній, етнічній, конфесійній, військовій і зовнішньополітичній сферах. За джерелами дестабілізації доречно визначити зовнішні, внутрішні й трансграничні загрози. За способами тиску на владу виділяються силові та несилові загрози. Суб'єктами загроз суспільно-політичній стабільності можуть бути держави, незаконні збройні формування, терористичні організації, сепаратистські рухи та ін.

Під стабілізацієюЮ. Бакаєв пропонує розуміти комплекс заходів державної політики, який спрямований на запобігання кризових явищ в економічній, політичній та соціальній сферах. Стабілізація виступає вирішальною передумовою та першим етапом подолання кризи в зазначеній галузі. У такому контексті необхідно мати на увазі, що стабілізація $€$ необхідним, але недостатнім елементом більш широкого державно-управлінського явища - антикризової політика. Антикризова політика, яка зводиться лише до однієї стабілізації, не може забезпечити тривалий успіх [5, с. 671].

До третього рівня категоріального апарату теорії державного управління відносяться поняття "технології державного реагування на загрози національній безпеці", "методи державного реагування на загрози національній безпеці", "профрілактика та протидія загрозам суспільно-політичній стабільності", "система профілактики та протидії загрозам суспільно-політичній стабільності", "механізм профрілактики загрозам суспільно-політичній стабільності", "комплексний механізм протидії загрозам суспільно-політичній стабільності". Як вказує М. Шевченко, під технологіями державного реагування на загрози національній безпеці пропонуємо розуміти цілеспрямовану послідовність дій (робочих операцій), які на основі відповідних методів і засобів за рахунок впливу на об'єкт національної безпеки дають змогу забезпечити захист національних інтересів [9, c. 218]. Методи державного реагування на загрози національній безпеці - це сукупність засобів, способів і прийомів впливу органів державної влади на події, явища, процеси інші чинники, які породжують небезпеки реалізації національних інтересів. Ці методи суттєво залежать від вибору концептуального підходу щодо реагування на загрози національній безпеці, під яким розуміється система прийнятих на офріційному рівні принципів, підходів та поглядів стосовно механізмів захисту національних цінностей та реалізації національних інтересів [9, с. 219].

У науковому дискурсі в залежності від стадії фрормування та реалізації загроз суспільно-політичній стабільності виокремлюють такі види управлінської діяльності, як профрілактика та протидія [10, с. 312].

Під профрілактикою розуміють процес впливу силами і засобами системи забезпечення національної безпеки на причини, що породжують загрози суспільнополітичній стабільності, а також на умови, що сприяють їх виникненню та реалізації. Видами протидії загрозам суспільно-політичній стабільності є: попередження, під яким розуміють вплив на процес підготовки та реалізації загрози суспільно-політичній стабільності; припинення, під яким розуміють безпосередній вплив на процес дестабілізації суспільно-політичної ситуації; локалізація, під якою розуміють процес усунення силами і засобами системи забезпечення національної безпеки шкідливих наслідків дестабілізації суспільно-політичної ситуації або зведення їх до мінімального рівня.

Під системою профрілактики та протидії загрозам суспільно-політичній стабільності пропонуємо розуміти організовану державою систему державних і недержавних інститутів, які із застосуванням політико-правових, ідеологічних, адміністративних, організаційноуправлінських, соціально-психологічних, фрінансовоекономічних, інформаційно-комунікативних та інших заходів забезпечують суспільно-політичну стабільність.

Під механізмом профрілактики загроз суспільнополітичній стабільності в контексті забезпечення національної безпеки пропонуємо розуміти сукупність державних інститутів та інститутів громадянського суспільства, які функціонально об'єднанні єдиним задумом впливу силами і засобами системи забезпечення національної безпеки на причини, що породжують загрози суспільно-політичній стабільності, а також на умови, що сприяють їх виникненню та реалізації.

Під комплексним механізмом протидії загрозам суспільно-політичній стабільності в контексті забезпечення національної безпеки пропонуємо розуміти сукупність державних інститутів та інститутів громадянського суспільства, а також практичних заходів, важелів, стимулів, способів дій з визначення та організації (залучення) необхідних і достатніх матеріальних, духовних, людських ресурсів, інтеграції різних сорер суспільства з метою досягнення завдань попередження, припинення та локалізації загроз суспільно-політичній стабільності.

Отже, понятійно-категоріальний апарат проблематики забезпечення суспільно-політичної стабільності як достатньо самостійного явища об'єктивної реальності дає змогу в ідеалізованому, абстрактному вигляді уявити собі ті чи інші сторони цього процесу, виокремити суттєві елементи та ̈іх взаємозв'язок, побудувати план практичних дій, спрямованих на стабілізацію суспільства в контексті забезпечення національної безпеки.

\section{ВИСНОВКИ ТА ПЕРСПЕКТИВИ ПОАААЬШИХ РОЗВІАОК}

Попри суттєвий прогрес, які демонструють вітчизняні науковці, недостатня розробленість понятійно-категоріального апарату як проблематики національної безпеки, так і проблематики забезпечення суспільнополітичної стабільності, його суперечливе застосування в різних документах не дозволяють забезпечити ефрективну практичну діяльність з цих питань. Дається взнаки російський вплив на українське суспільство та його політичну систему, метою якого $є$ цілеспрямована дестабілізація України в максимально можливих напрямках. За таких умов, що склалися, доцільно дати законодавче визначення понять "суспільно-політична стабільність", "система профрілактики та протидії загрозам суспільно-політичній стабільності", "механізм профілактики загроз суспільно-політичній стабільності", 
"комплексний механізм протидії загрозам суспільнополітичній стабільності".

Визначення взаємозв'язку та ієрархічної послідовності понять "суспільно-політична стабільність - загрози суспільно-політичній стабільності - система профілактики та протидії загрозам - практичні механізми профрілактики та протидії", їх імплементація у суспільну свідомість та корпоративну культуру висуваються на першочергові позиції в державно-управлінській сфері. Субординація цих термінів має обов'язково враховуватись при підготовці наступних документів: Доктрини суспільно-політичної стабільності - Стратегії суспільнополітичної стабільності - Державної цільової програми забезпечення суспільно-політичної стабільності. У разі дотримання запропонованої послідовності розробки нормативно-правових актів діяльність щодо посилення стабільних засад життєдіяльності українського суспільства набуде чіткості, цільової визначеності та вербальної завершеності.

У цьому контексті назрілим науковим завданням виглядає визначення особливостей забезпечення суспільно-політичної стабільності: а) в мирних умовах еволюції соціуму; б) в умовах цілеспрямованого продукування зовнішнім політичним середовищем (сусідньою державою) широкого спектру ризиків, спрямованих на дестабілізацію української держави і суспільства; в) в умовах зовнішньої стабілізаційної допомоги та г) в умовах її послаблення або відсутності.

\section{Література:}

1. Про основи національної безпеки України / Закон України від 19.06.2003 р. [Електронний ресурс]. Режим доступу: http://zakon3.rada.gov.ua/laws/ show $/ 964-15$

2. Шляхи удосконалення системи державного управління забезпеченням національної безпеки України [Текст]: монографрія / Г. Ситник, В. Абрамов, О. Бортнікова та ін.; за ред. Г. Ситника, В. Абрамова. - К.: МАЙСТЕР КНИГ, 2012. - 536 с.

3. Про національну безпеку України / Закон України від 21.06.2018 р. [Електронний ресурс]. - Режим доступу: https://zakon.rada.gov.ua/laws/show/246919\#n355

4. Литвиненко О.В. Спеціальні інформаційні операції та пропагандистські кампанії: монографрія / О.В. Литвиненко. - К.: ВКФ "Сатсанта", 2000. - 222 с.

5. Ситник Г.П. Стабільність політична /Г.П. Ситник/ / Енциклопедичний словник з державного управління / Уклад.: Ю.П. Сурмін, В.Д. Бакуменко, А.М. Михненко та ін.; за ред. Ю.В. Ковбасюка, В.П. Трощинського, Ю.П. Сурміна. - К.: НАДУ, 2010. - 820 с.

6. Гошовська В. Стабільність політична / В. Гошовська / / Політологія: навчальний енциклопедичний словник-довідник / За наук. ред. Н.М. Хоми. - Львів: "Новий Світ - 2000", 2014. - 779 с.

7. Шевченко М.М. Поняття "суспільно-політична стабільність": смисловий простір державно-управлінського змісту / М.М. Шевченко, О.Г. Давиденко / / Інвестиції: практика та досвід. - 2016. - № 14. - С. 49-54.

8. Арон Р. Демократия и тоталітаризм: монография / Р. Арон / Пер. с фрранц. Г. Семенова. - М.: Текст, 1993. -303 c.
9. Шевченко М.М. Філософрія праксису державного реагування на загрози національній безпеці / М.М. Шевченко / / Управлінські науки в сучасному світі: Збірник матеріалів II Міжнародн. наук.-практ. конфр. (Київ, 1011 грудня 2015 р.). - Київ, 2015. - Т. 1. - С. 217 220.

10. Шевченко М.М. Методи державного реагування на загрози національній безпеці / Енциклопедія державного управління: у 8 т. / Нац. акад. держ. упр. при Президентові України; наук.-ред. колегія: Ю.В. Ковбасюк (голова) та ін. - К.: НАДУ, 2011. - Т. 2: Методологія державного управління / Наук.-ред. колегія: Ю.П. Сурмін (співголова), П.І. Надолішній (співголова) та ін. - 2011. - С. 312-313.

\section{References:}

1. Verkhovna Rada of Ukraine (2003), The Law of Ukraine "On the Fundamentals of National Security of Ukraine", available at: http://zakon3.rada.gov.ua/laws / show /964-15 (Accessed 20 Feb 2019).

2. Sytnyk, H. Abramov, V. and Bortnikova, O. (2012), Shliakhy udoskonalennia systemy derzhavnoho upravlinnia zabezpechenniam natsional'noi bezpeky Ukrainy [Ways to improve the system of public administration ensuring the national security of Ukraine], MAJSTER KNYH, Kyiv, Ukraine.

3. Verkhovna Rada of Ukraine (), The Law of Ukraine "On of National Security of Ukraine", available at: https:/ /zakon.rada.gov.ua/laws/show/2469-19\#n355 (Accessed 20 Feb 2019).

4. Lytvynenko, O.V. (2000), Spetsial'ni informatsijni operatsii ta propahandysts'ki kampanii [Special information operations and advocacy campaigns],VKF "Satsanta", Kyiv, Ukraine.

5. Sytnyk, H.P. (2010), "Stability is political", Entsyklopedychnyj slovnyk z derzhavnoho upravlinnia [Encyclopedic Dictionary of Public Administration], NADU, Kyiv, Ukraine.

6. Hoshovs'ka, V. (2014), "Stability is political", Politolohiia: navchal'nyj entsyklopedychnyj slovnykdovidnyk [Politics: An educational encyclopedic dictionarydirectory], "Novyj Svit - 2000", Lviv, Ukraine.

7. Shevchenko, M.M. and Davydenko, O.H. (2016), "The concept of "socio-political stability": the semantic space of state-management content", Investytsii: praktyka ta dosvid, vol. 14, pp. 49-54.

8. Aron, R. (1993), Demokratyia y totalitaryzm [Democracy and totalitarianism], Tekst, Moscow, Russia.

9. Shevchenko, M.M. (2015), "The philosophy of praxis of the state response to threats to national security", Upravlins'ki nauky v suchasnomu sviti: Zbirnyk materialiv II Mizhnarodnoi naukovo-praktychnoi konferentsii [Management Science in the Modern World: A Collection of Materials of the 2nd International Scientific and Practical Conference], Kyiv, Ukraine, 10-11 Dec 2015, pp. 217-220.

10. Shevchenko, M.M. (2011), "Methods of State Response to Threats to National Security", Entsyklopediia derzhavnoho upravlinnia: u 8 t. [Encyclopedia of Public Administration: in 8 vol.], NADU, Kyiv, Ukraine, vol. 2, pp. 312-313.

Стаття надійшла до редакчї 26.02.2019p. 